\title{
Világháborús bombakráterek automatikus térképezése
}

\author{
Neuberger Hajnalka - Juhász Attila
}

DOI: https://doi.org/10.30921/GK.70.2018.5.4

\section{Bevezetés}

A II. világháború során a szembenálló felek óriási mennyiségú bombát dobtak le az ellenséges területekre. A háború befejezése óta eltelt több mint 70 év ellenére mind a mai napig komoly veszélyt jelentenek a fel nem robbant bombák, elég csak a viszonylag súrû́n elôforduló ezzel kapcsolatos híradásokra gondolnunk, amikor különböző építkezéseken kerülnek elố a föld alól ezek a veszélyes objektumok. Korábbi kutatások és a szakirodalom alapján kijelenthetjük, hogy a ledobott bombák legalább 10\%-a nem robbant fel (Brenner et al. 2018). 1974 óta, csak Magyarországon több, mint 5 millió darab lőszert, robbanótestet hatástalanítottak a különbözó tûzszerész-szolgálatok munkatársai. Ezek döntô többsége lejárt szavatosságú lôszer volt, és csak 1-2\%-nyi mennyiséget jelentettek a bombák, amelyeknek azonban kiemelt a jelentôségük a veszélyességük miatt (Linder 2008). A fel nem robbant bombák nagy része településeken belül kerül elô, ahol mai felvételek alapján sajnos nincs sok esély távérzékelési, térinformatikai módszerekkel az elôzetes felderítésükre, potenciális előfordulási területeik lehatárolására. Kutatásunkban ezért mi is a külterületekre koncentráltunk. Az eljárásunk alapját a vizsgált területen végrehajtott automatikus bombakráter-detektálás jelenti, melynek eredményét bombázási és kockázati térképek elôállítására használjuk fel a késôbbiekben. Emellett az azonosított kráterek segítséget nyújthatnak világháborús katonai objektumok rekonstrukciójának támogatására is. Az elôbbi megoldásra talán a legismertebb nemzetközi példa London bombázottsági adatbázisa (Marchionni et al. 2013). A szúkebb katonai, hadtörténeti alkalmazás mellett más területeken is felhasználható az eljárásunk, például a töbrök (Látos et al. 2016), kátyúk, égitestek természetes krátereinek térképezésére (Cohen et al. 2016).
A kockázati térképet egyfajta tematikus térképnek tekinthetjük, amelyen megjelenítjük egy vizsgált terület bombakrátereit és azok szúkebb környezetét, amelyek potenciálisan veszélyt jelenthetnek a fel nem robbant bombák miatt (Szikszai 2018). A kulcsfeladat tehát, a sokszor nagyszámú kráter megbízható azonosítása és térképezése. A nemzetközi szakirodalomban több ez irányú kutatással is találkozhatunk, amelyek archív légi fotókat használnak fel a különbözô eljárásokhoz. Jellemzôen neurális hálózatokkal (Brenner et al. 2018), illetve az úgynevezett „marked point process" eljárással történô megvalósításokat publikáltak (Kruse et al. 2017). Ezzel szemben - a fényképek felhasználásának komoly nehézségeit is figyelembe véve -, mi légi lézerszkennelt adatokat használtunk fel a kutatásainkban. Ezek egy része a németországi OpenNRW-projektből származik, melyben Észak-Rajna-Vesztfália területérôl nagy mennyiségú és változatos térbeli adatokat tettek ingyenesen elérhetôvé (Isenburg 2017). A két mintaterület: Emmerich am Rhein $146 \mathrm{~km}^{2}$ területtel, valamint Rheine $186 \mathrm{~km}^{2}$ kiterjedéssel. A salzgitteri adatokat, amelyek $281 \mathrm{~km}^{2}$-es területet fednek le, a hannoveri Leibniz Egyetem Fotogrammetria és Térinformatikai Intézetétől kaptuk meg.

A LiDAR-adatokon alapuló vizsgálatoknak számos elônye van az archív légi felvételekkel szemben:

- nem jelentkezik a felhőzet és a terepi objektumok által okozott kitakarás és árnyékolás,

- a sokszor nagyon rossz minôségú részleteket is tartalmazó archív légi felvételekkel szemben homogénnek tekinthetố nagy sûrúségú pontfelhővel dolgozhatunk,

- közvetlenül kinyerhetố egy nagy pontosságú terepmodell a pontfelhőból, akár vegetációval borított területeken is, aminek esetünkben kiemelt jelentősége van.

Természetesen a hátrányokról sem feledkezhetünk meg, amelyek közül a legjelentôsebb a felvétel készítésének időpontja, a lézerszkennelt állományok a mai állapotról szolgáltatnak információt. Mivel a légi felvételek a háború alatt, illetve közvetlenül utána készültek, nyilvánvalóan teljesebb képet adnak a bombázottságról. Kihívást jelent továbbá, hogy a legtöbb képfeldolgozó eljárás valódi képekre van kidolgozva, így ezek használata terepmodelleken több esetben is módosításokat igényel.

\section{A kockázati térképezést megalapozó eljárás}

A bombázási és kockázati térképek alapjául egy olyan eljárást fejlesztettünk ki, ami lehetôvé teszi nagy területek átfogó vizsgálatát, és minimális felhasználói beavatkozást igényel. Az eljárás fontosabb lépéseit és az ezeket befolyásoló tényezőket az alábbiakban tekintjük át.

Elsôként, - figyelembe véve azt a lehetôséget is, hogy akár országos területi kiterjedésú vizsgálatra is sor kerülhet - kidolgoztunk egy módszert a potenciálisan feldolgozandó területek hatékony leválogatására, ami nagyban csökkenti a kutatómunka idô- és erốforrásigényét. A korábbi tapasztalatok azt mutatják, hogy az elmúlt évtizedek során szinte kizárólag erdôs, fás, ligetes területeken maradtak fenn szignifikáns nyomai a bombázásoknak. Ebból kiindulva a területi leválogatás alapjául az OSM (OpenStreetMap) térképi adatai közül az erdôfedvényt használtuk fel. A módszer lényegében szabályos négyzetrácsokra bontja a területet, majd megvizsgálja az erdôk részarányát az egyes rácsokban. Ha a részarány egy bizonyos határérték alatt van, akkor további, kisebb rácselemek következnek. Így egy adaptív eljárást kapunk, amely folyamatosan zárja ki a vizsgálatból a hasznos információt nem tartalmazó „üres” területegységeket, valamint a megtartott rácselemek esetében a minél nagyobb potenciális vizsgálati területarányra törekszik 


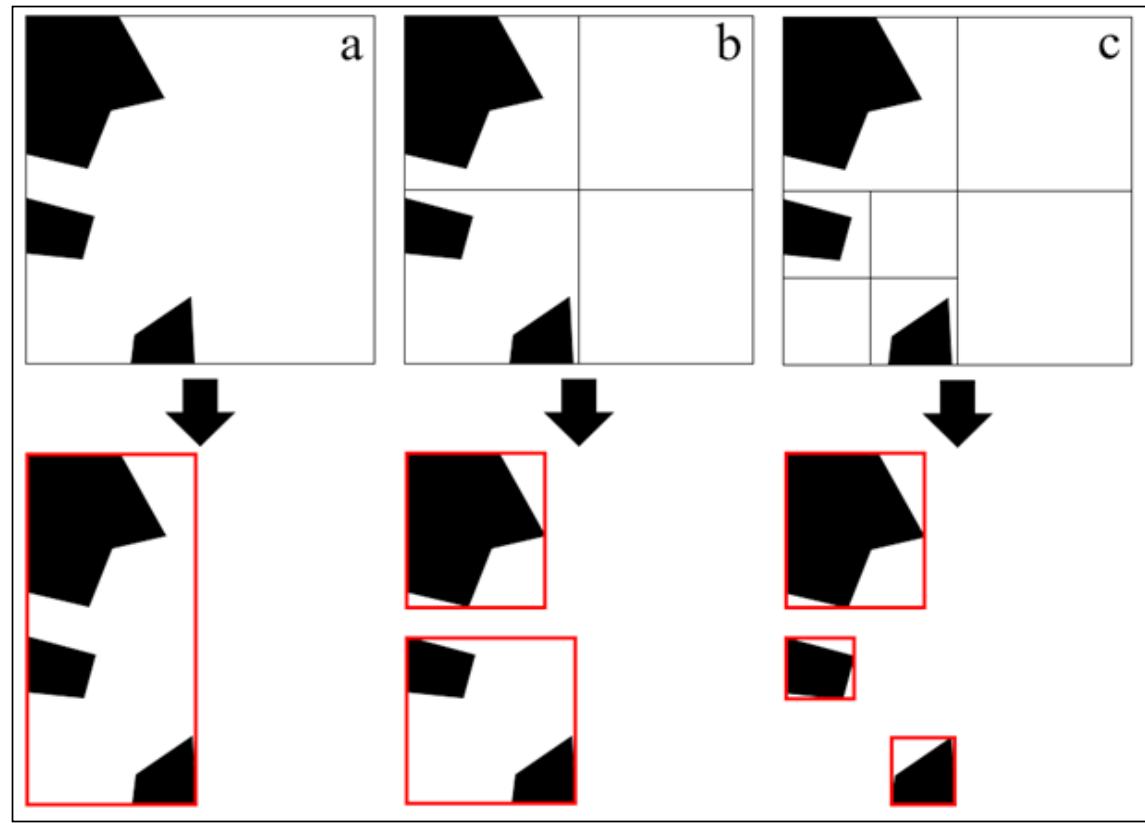

1. ábra. Potenciális területleválogató eljárás lépései és eredményeik

a) teljes terület, b) terület felosztása négy részre, c) szükség szerint az egyes területek továbbosztása)

A kráterdetektálás eredményei a mintaterületeken

1. táblázat.

\begin{tabular}{|c|c|c|c|c|c|c|}
\hline & $\begin{array}{c}\text { Kráter- } \\
\text { szám (ref) }\end{array}$ & $\begin{array}{c}\text { Valós } \\
\text { találat }\end{array}$ & $\begin{array}{c}\text { Téves } \\
\text { találat }\end{array}$ & $\begin{array}{c}\text { Teljesség } \\
(\%)\end{array}$ & $\begin{array}{c}\text { Helyesség } \\
(\%)\end{array}$ & $\begin{array}{c}\text { Minôség } \\
(\%)\end{array}$ \\
\hline Salzgitter & 33 & 30 & 0 & 90,9 & 100,0 & 90,9 \\
\hline Rheine 1 & 56 & 35 & 5 & 62,5 & 87,5 & 57,4 \\
\hline Rheine 2 & 37 & 27 & 21 & 73,0 & 56,2 & 46,6 \\
\hline
\end{tabular}

Teljesség = Valós találat $/$ Referenciakráterek száma

Helyesség = Valós találat $/$ (Valós + Téves találatok)

Minốség = Valós találat / (Referencia kráterek + Téves találatok $)$

(1. ábra). Az esetlegesen elôforduló méretükból adódóan - nem releváns, kis erdôrészletek törlése után előállnak azok a maszkok, amelyek segítségével az eredeti LiDAR-állományból kimetszhetjük a további vizsgálatok alapját képezó pontfelhőrészleteket (Juhász - Neuberger 2018).

A leválogatott területekre esố állományok nagysága még így is jelentôsnek tekinthetô, ezért a következó lépést a LiDAR-pontfelhô méretének radikális csökkentése jelentette. A cél az volt, hogy a célobjektumok és a terep jellegzetes pontjai megmaradjanak, de a kutatás szempontjából irreleváns pontokat minél nagyobb számban elimináljuk. A kutatás során több módszert is teszteltünk, kerülve a szabályos ritkítási eljárásokat, amelyeket ez esetben nem tartunk megfelelốnek. Tapasztalataink szerint az az eljárás vezetett a legjobb eredményre, amely egy vizsgált pont $1 \mathrm{~m}^{2}$-es körzetében csak azokat a pontokat tartja meg, amelyek magassága egy bizonyos küszöbértéknél nagyobb mértékben eltér ettől a kiválasztott ponttól. A küszöbérték növelésével a pontfelhô mérete jelentősen csökkenthetô. Esetünkben 10-20\%-ra redukálható a pontfelhố mérete, de egy minimálisan megadott pontszám alá (ami akár az egyetlen vizsgált pont is lehet) nem kerülhetünk (NeubergerJuhász 2016).

$\mathrm{Az}$ így rendelkezésre álló, előfeldolgozott adatok képezték az alapját a harmadik lépésnek, ami a kráterdetektálási eljárás. Ez a módszer digitális képfeldolgozási múveleteket hajt végre meghatározott sorrendben a LiDAR-adatokból levezetett raszteralapú digitális terepmodellen (DTM). A múveletek sorrendben a következók: trendfelület generálása simításokkal, különbségkép képzése az eredeti és a trendfelületbôl, küszöbölés, irrelevánsan kicsi és nagy pixelfoltok törlése, morfológiai

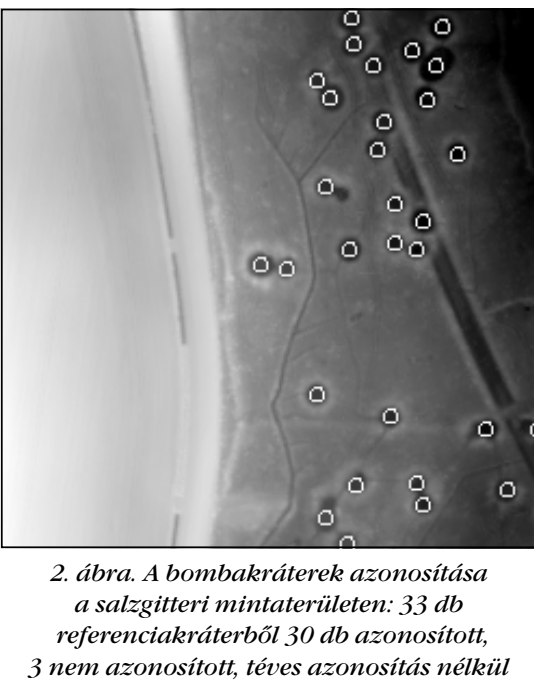

szúrôk alkalmazása, végül a törlés megismétlése (Neuberger et al. 2017). Az így elért eredményeket tovább javítottuk a potenciálisan kráterként azonosított pixelhalmazok körszerúségének vizsgálatával, az alábbi képlet felhasználásával (Mallick 2015). Szabályos kör esetén ez az érték maximum 1 lehet.

Az esetlegesen átfedố kráterek azonosításához a „Distance transform” megoldást alkalmaztuk (Distance Transform Documentation 2017). Az eljárás minden pixel esetén kiszámolja, hogy mi a legkisebb távolság az objektum széléhez viszonyítva, bináris képeken. Így az objektum súlypontjában a legnagyobb, a körvonalat az egyes érték jelzi, ha pedig nem az objektum része egy pixel, akkor a nulla értéket vesz fel.

A leírt eljárást alkalmazva több mintaterületen is jó eredményeket értünk el. (1. táblázat). Az egyes területeken a referenciakráterek számát manuálisan, tapasztalatainkra támaszkodva határoztuk meg $\mathrm{Az}$ algoritmus paraméterei az elsố területre lettek optimalizálva (2. ábra), nagy valószínúséggel a 2. és 3. területek esetében is jobb eredmények érhetôk el a paraméterek területspecifikus definiálásával.

\section{A kockázati térkép elkészítése}

A kockázati térkép alapvetô funkciója, hogy tájékoztassa a felhasználót az ábrázolt területen lévố különbözô mértékú veszélyességi értékekkel rendelkező részterületek térbeli 
eloszlásáról. A korábban már említett külföldi kutatócsoportok több különbözô eljárást is alkalmaztak a kockázati térképek generálására (Kruse et al. 2018). Figyelembe véve a későbbi, potenciális felhasználókör igényeit és gyakorlatát, mi a szabályos négyszögrács alapú térképezés mellett döntöttünk. A régészetben, roncskutatásban, illetve a tûzszerészi gyakorlatban is döntôen a szabályos négyzet vagy téglalap felosztást használják a terepi munkákban. A tematikát tekintve, alapvetôen három (veszélyességi) osztályt különböztettünk meg, amelyeket eltérô színekkel jelöltünk (3. ábra).

- Piros színnel jelöltük a legkockázatosabb területeket, ahol az adott területegységre több, mint egy kráter esik. Egy esetleges terepi vizsgálat során mindenképpen ezekkel a területekkel célszerú kezdeni a bombamentesítést.

- Sárgával azokat a potenciális területeket jelöltük, amelyeket pontosan egy kráter volt található. Emellett biztonsági megfontolások miatt, a piros területek szomszédjai is sárga színt kaptak. Továbbá, ha egy sárga egység szélén (pl. 10 méteres pufferben) helyezkedett el egy detektált kráter, akkor ebben az esetben is sárga színt kapott a szomszédos terület is.

- A krátermentes részek zöldek.

A kockázati térkép elkészítésének másik fontos paramétere volt a megfelelố felbontás. Mindhárom mintaterületen több felbontás is teszteltünk 10 métertől 100 méterig (3. ábra), (2. táblázat), melyek közül az 50 méterest ítéltük a legcélravezetôbbnek. A kisebb méret ellen szól, hogy azokban a felbontásokban szinte csak a bombakráterek reprezentálták a legveszélyesebb területegységeket (a méretük miatt) nagyon széttagoltan, és csak a nagyon szúk környezetük a még potenciálisan vizsgálandó (sárga) területeket (3. ábra a) része). Emellett, a kisebb méretû́ rácselemek esetében olyan „biztonságos” folyosók keletkezhetnek a térképen, amelyek véleményünk szerint nem életszerúek, nem hagyhatók ki a gyakorlati bombakeresésból (3. ábra). 100 méteres felbontás esetében (3.. ábra d) része) viszont már relatíve nagy, veszélyesnek ítélt területek álltak

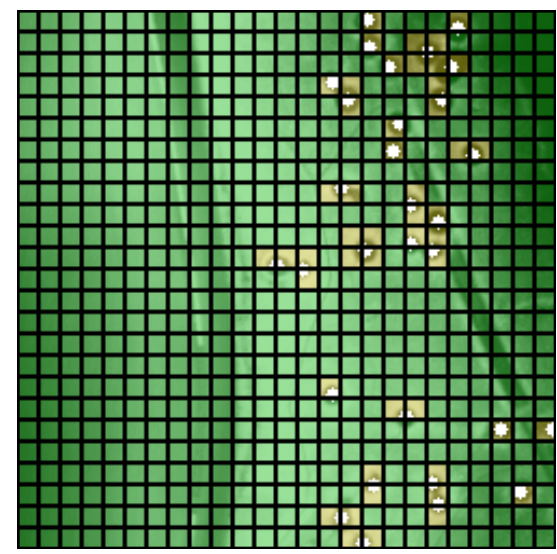

3. a) ábra. 10 m-es felbontás (Salzgitter)

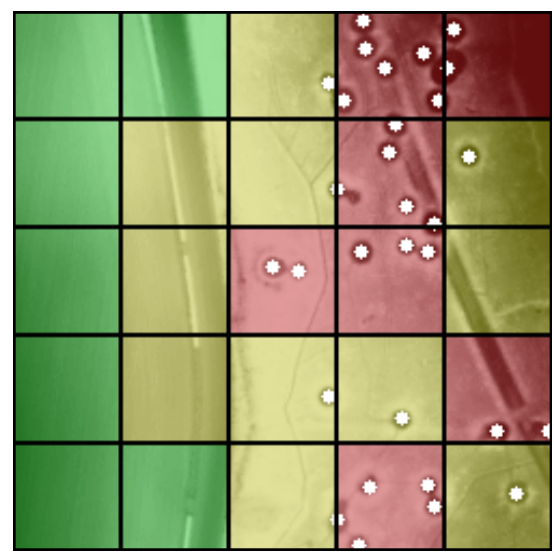

3. c) ábra. 50 m-es felbontás (Salzgitter)

elô, ami fokozott biztonsági szempontból akár indokolt is lehet. Azonban ez jóval nagyobb költséget is jelent, tekintettel a bombakeresés gyakorlati megvalósítása. Természetesen igény esetén eltérô felbontású kockázati térképek előállítására is van mód a különbözô - lokálistól a regionális, országos szintig terjedố céloknak megfelelốen. Emellett a beazonosított kráterek alapján pufferzónák is generálhatók térinformatikai alkalmazásokban.

A tesztek során kezelnünk kellett azokat az eseteket is, amikor a kiválasztott kockázati térképi rácselem nagysága nem volt kompatibilis az adott szelvények méretével. A Salzgitter terület egy 250 × 250 m-es kivágat, ahol a 100 m-es felbontású kockázati térkép

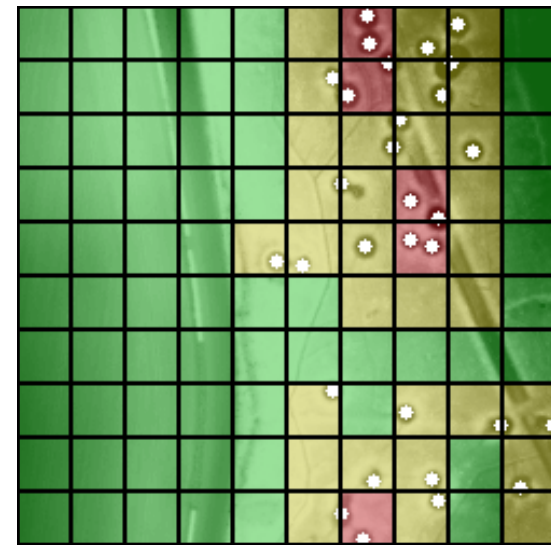

3. b) ábra. 25 m-es felbontás (Salzgitter)

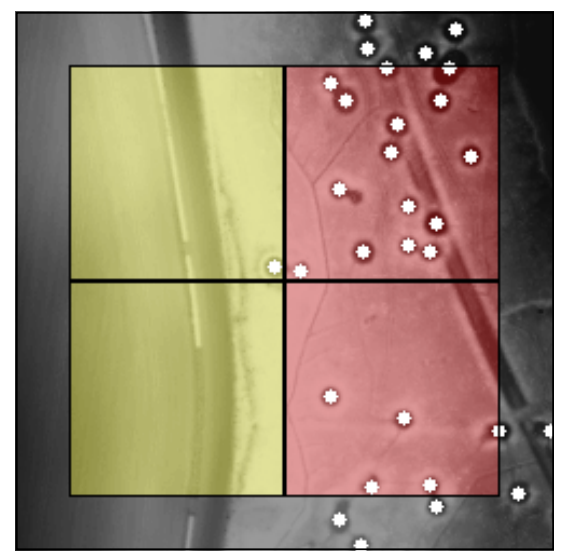

3. d) ábra. 100 m-es felbontás (Salzgitter)

elkészítése értelemszerúen nehézségekbe ütközik. Az algoritmusunk azonban bármilyen méretú szelvény és felbontás kombinációját képes kezelni, néhány megkötéssel:

- A kockázati térkép minimális felbontása a szelvény nagyságával egyezik meg. Például, ha egy 500 m-es felbontás szeretnék egy 250 × 250-es területen, akkor a felbontás 250-re fog változni, automatikusan.

- Természetesen a felbontás nem lehet negatív, azonban felhasználói hibák előfordulhatnak. Ekkor a program figyelmeztet erre, és kéri a valós felbontást.

- A 3. ábra d) részének megfelelôen, ha a szelvény területe nem osztható maradéktalanul a felbontással,

A különbözố veszélyességú területek részaránya a felbontás tekintetében

2. táblázat

\begin{tabular}{|l|c|c|c|c|c|c|c|c|}
\hline & \multicolumn{2}{|c|}{10 m-es felbontás } & \multicolumn{2}{|c|}{25 m-es felbontás } & \multicolumn{2}{c|}{50 m-es felbontás } & \multicolumn{2}{c|}{100 m-es felbontás } \\
\cline { 2 - 9 } & Piros \% & Sárga \% & Piros \% & Sárga \% & Piros \% & Sárga \% & Piros \% & Sárga \% \\
\hline Salzgitter & 0 & 15 & 5 & 37 & 28 & 44 & 50 & 50 \\
\hline Rheine 1. & 0 & 8 & 1 & 25 & 15 & 45 & 50 & 50 \\
\hline Rheine 2. & 0 & 3 & 0 & 11 & 4 & 35 & 28 & 53 \\
\hline
\end{tabular}


akkor a szelvény közepén zajlik a vizsgálat, a széleket arányosan kihagyva. Ezek a részek amúgy is bizonytalanok, hiszen a szomszédos szelvényeken levő veszélyes területek is hatással lehetnek rájuk. A kapcsolódó szelvények együttes vizsgálata további kutatás részét képezi.

A programot teljesen egészében $\mathrm{C}++$ nyelven írtuk; a munkánk során csupán szabadon hozzáférhetó OpenCV (OpenCV 2018) függvényeket használtunk fel. Eredményül egy olyan szoftvert állítottunk elố, mely egy átlagos asztali számítógépen néhány másodperc alatt (a sebesség fóként a számítógép paramétereitôl, illetve a feldolgozandó terület nagyságától függ) tetszôleges terepmodellen megtalálja a bombakrátereket, és abból kimenetként egy kockázati térképet állít elô.

\section{4. Összefoglalás, kitekintés}

A kidolgozott, automatikusnak tekinthetô módszer alkalmas nagy területeken történó bombakráter-azonosításra és ezek alapján bombázottsági és kockázati térképek elkészítésére. Az algoritmus egyes lépéseiben használt paraméterek optimalizálásakor figyelembe kell venni a vizsgált terület nagyságát, a felbontást, a kutatott objektumok jellemzó méreteit, ami nagy tapasztalatot igényel. Reményeink szerint elôbbutóbb sor kerülhet országos szintú magyarországi adatok feldolgozására is, melynek eredményeképpen egy átfogó kockázati elemzés készülhet. Eredményeink felhasználhatók egyegy nagyobb terület bombamentesítésének idő- és költségkalkulációjához is.

A fentiekben bemutatott, speciálisnak tekinthetô alkalmazási terület mellett az eljárás, vagy annak egyes alkotóelemei, felhasználhatók minden olyan területen ahol pontfelhôk feladatspecifikus leválogatása, ritkítása, illetve lokálisan elôforduló magasságkülönbségek detektálása a feladat. Ilyen lehet a karsztos területeken megfigyelhetố töbrök azonosítása, égitestek krátereinek térképezése, vagy akár útállapot felmérésének támogatása a kátyúk detektálásával, és a rossz minôségú utak kockázati térképezésével.

\section{Irodalom}

Brenner, S.- Zambanini, S.- Sablatnig, R 2018. Detection of Bomb Craters in WWII Aerial Images. Proceedings of the OAGM Workshop 2018, pp. 94-97. DOI: $10.3217 / 978-3-85125-603-1-20$

Cohen, J. P. - Lo, H. Z. - Lu, T. - Ding, W. 2016 Crater Detection via Convolutional Neural Networks. 47th Lunar and Planetary Science Conference (LPSC 2016), pp. 1-2.

Distance Transform Documentation. 2017. OpenCV: Image Segmentation with Distance Transform and Watershed Algorithm. https://docs.opencv.org/3.3.0/ $\mathrm{d} 2 / \mathrm{dbd} /$ tutorial distance transform.html, utolsó elérés: 2018. 8. 14.

Isenburg, M. 2017. First Open LiDAR in Germany | rapidlasso GmbH. https:// rapidlasso.com/2017/01/03/first-openlidar-in-germany/, utolsó elérés: 2017. 10. 13

Juhász, A. - Neuberger, H. 2018. Automatic selection of potential WWII bombed areas by using spatial data. Pollack Periodica, 13. évf. pp. 173-183. DOI: 10.1556/606.2018.13.2.17

Kruse, C. - Neuberger, H. - Rottensteiner, F. - Hoberg, T. - Ziems, M. - Huth, J. Heipke, C. 2017. Automatische Detektion von Bombenkratern in Kriegsluftbildern mittels markierter Punktprozesse. 37. Wissenschaftlich-Technische Jahrestagung der DGPF in Würzburg, pp. 245-261.

Kruse, C. - Rottensteiner, F. - Hoberg, T. Ziems, M. - Rebke, J. - Heipke, C. 2018. Generating impact maps from automatically detected bomb craters in aerial wartime images using marked point processes. ISPRS Ann. Photogramm. Remote Sens. Spatial Inf. Sci., IV. évf. pp. 127-134. DOI: 10.5194 isprs-annals-IV-3-127-2018

Látos, T. -. Telbisz, T. - Deák, M. - Székely, B. - Koma, Z. - Standovár, T. 2016. LiDAR és topográfiai térkép alapú digitális terepmodellekből levezetett, illetve kézzel digitalizált töbör-körvonalak morfometriai összehasonlítása az Aggteleki-kraszt példáján. Karsztfejlôdés $X X$., pp. 145-165.

Linder 2008. Fel nem robbant bombák - A hibahatáron belül. http://magyarnarancs.hu/ tudomany/fel nem robbant bombak - a hibahataron belul-68929, utolsó elérés: 2018. 7. 12 .

Mallick, S. 2015. Blob Detection Using OpenCV (Python, C++) | Learn OpenCV. https:// www.learnopencv.com/blob-detectionusing-opencv-python-c/, utolsó elérés: 2018. 8. 14.

Marchionni, P. - Findlay, P. - Dunning, A. Southall, H. - Heally, R. - Aucott, P. - Ladd, B. - Brown, M. 2013. Bomb Sight - Mapping the World War 2 London Blitz Bomb Census. http://www.bombsight.org/, utolsó elérés: 2018.7.5.

Neuberger, H. - Juhász, A. 2016. Objektum detektálás LiDAR adatokból a pontsưrúség függvényében. Az elmélet és a gyakorlat találkozása a térinformatikában VII. Debrecen, pp. 345-352.
Neuberger, H. - Juhász, A. - Kruse, C. 2017. Automatic detection of World War II objects based on air-borne LiDAR data. Az elmélet és a gyakorlat találkozása a térinformatikában VIII., Debrecen, pp. 259-265.

OpenCV. 2018. OpenCV library. https://opencv. org/, utolsó elérés: 2018. 8. 14.

Szikszai, C. 2018. Magyarország II. világháborús bombázottsági adatbázisának tervezése. Az elmélet és a gyakorlat találkozása a térinformatikában IX., Debrecen, pp. 341-347.

\section{Summary}

After more than 70 years the remained unexploded bombs of the World War II still pose a serious threat. In this paper a method is presented about how can be the bomb craters detected and mapped from LiDAR data in an automatic way. Firstly, the potential areas must be delineated, where the bomb craters can be found. Secondly, the huge amount of data must be reduced considering the time and resource needs of the research. Digital terrain model can be generated from LiDAR data easily and the craters can be found by analyzing the local height differences. The output of this process is a risk map, which can help to prioritize the most dangerous areas.

Kulcsszavak: bombakráter, kockázati térkép, LIDAR, automatikus térképezés

Keywords: bomb crater, risk map, LIDAR, automated mapping

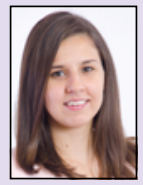

Neuberger

Hajnalka

doktorjelölt

BME Fotogrammetria és Térinformatika Tanszék neuberger.hajnalka@epito.bme.hu

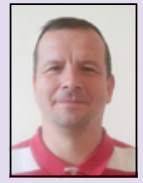

Dr. Juhász

Attila adjunktus

BME Fotogrammetria és Térinformatika Tanszék juhasz.attila@epito.bme.hu 